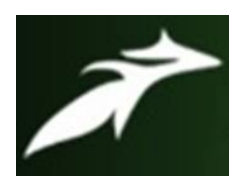

Ranjitha. B et al, International Journal of Advances in Agricultural Science and Technology,

Vol.8 Issue.8, August-2021, pg. 33-41

\title{
A Study on Relationship between Body Condition Score (BCS) and Milk Yield, Fat and Solids-Not-Fat Percent in Murrah Graded Buffaloes under Field Conditions
}

\author{
Ranjitha. B' ; Ashalatha. $P^{2}$; Jagadeeswara Rao. S3; Subrahmanyeswari. $B^{4}$ \\ ${ }^{1}$ MVSc Scholar, Department of LPM, NTR College of Veterinary Science, Gannavaram, SVVU, Andhra Pradesh, India \\ ${ }^{2}$ Professor, Department of LPM, NTR College of Veterinary Science, Gannavaram, SVVU, Andhra Pradesh, India \\ ${ }^{3}$ Retd. Professor, Department of LPM, NTR College of Veterinary Science, Gannavaram, SVVU, Andhra Pradesh, India \\ ${ }^{4}$ Professor \& Head, Department of VAE, NTR College of Veterinary Science, Gannavaram, SVVU, Andhra Pradesh, India \\ DOI: 10.47856/ijaast.2021.v08i8.003
}

\begin{abstract}
The present experiment was a study on the relationship of Body Condition Score with milk yield, fat and solids-not-fat percent in murrah graded buffaloes under field conditions. In this murrah graded buffaloes from different commercial farms of Guntur and Krishna districts were selected. Total of 150 murrah graded buffaloes of different parities $\left(1^{\text {st }}\right.$ to $6^{\text {th }}$ parities) were selected. Various parameters like BCS, related to average milk yield, fat per cent, SNF per cent was taken into consideration for the present study and a correlated study of BCS and the milk yield was studied.

The selected animals were divided into four groups based on BCS as 2.5-2.99, 3.0-3.49, 3.5-3.99, 4.0-4.49. The mean BCS values of 2.5-2.99, 3.0-3.49, 3.5-3.99, 4.0-4.49 were $2.62,3.25,3.56$ and 4.25 respectively. Highest milk yield was recorded in second month of lactation and lowest in first month of lactation with $9.445 \pm 0.15$ and $6.18 \pm 0.08 \mathrm{~kg}$ per day, respectively. The buffaloes with BCS $4.0-4.49$ yielded higher milk yield when compared to other groups. Highest fat and SNF percent was observed in the animals with BCS 4.0-4.49 when compared with others. The BCS had showed high positive correlation with SNF (0.44) and milk yield (0.41).
\end{abstract}

\section{INTRODUCTION:}

The world buffalo population is found to be 199.784 million (FAO 2015) and 56.6\% Buffaloes are in India. During the last 10 years, an annual growth of buffalo population was $1.49 \%$ and $1.53 \%$ in the world and India respectively. There are 108.70 millions buffaloes in India which contribute $21.23 \%$ of the total livestock population in India. The female buffalo population has increased by $7.99 \%$ over the previous census and the total number of female buffalo is 92.5 million in 2012 (19th livestock census). India ranks first among the world's milk producing nations with production of 146.3 million tons during 2014-15 and contributing $17.4 \%$ of world milk production. The buffalo milk alone contributes $51 \%$ of the total milk production in the India. Andhra Pradesh endowed with buffalo population of 10.6 million with a milk production of 7.4 metric tonnes (GOI 2017). About $72 \%$ of the milk produced in Andhra Pradesh comes from the buffaloes. It is one of the major buffalo milk producing states of the country.

Buffaloes are preferred over cattle in India because of their distinctive qualities such as better feed conversion efficiency, more resistance to diseases and higher milk fat percentage than in cows. Moreover, buffalo can efficiently convert low quality feed stuffs like straws and agro industrial waste into human food and improve soil structure through bio 


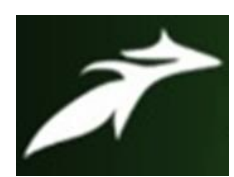

Ranjitha. B et al, International Journal of Advances in Agricultural Science and Technology,

Vol.8 Issue.8, August-2021, pg. 33-41

ISSN: 2348-1358

Impact Factor: 6.057

NAAS Rating: 3.77

fertilizer. When the buffalo rearing has shifted from the backyard to commercial farms, popularity of buffalo milk has ensured buffalo production as a main stay in the path of the dairy industry in India. However, for this species to perform optimally under the pressure of intensive production systems, the animals have to be improved with clear focus on the desired output.

Body Condition Score (BCS) is a subjective measure of body energy reserve and is used as an indirect indicator of energy balance status. It was based on the visual observation and palpation of vertebral column, transverse process, tail head region and ribs of animal. It is a critical measure of dairy feeding system effectiveness. Optimal body condition of dairy animal is important for obtaining elite herd and quantity milk production, because low or excessive body energy reserve may have a greater risk of lower milk yield. Therefore, ideal BCS not only optimises milk yield, but also maximises economic returns. In order to derive the maximum potential from native buffaloes and for their better management, there is a need to evaluate their fitness used to assess and improve the reproduction and production status of buffaloes.

In the state of Andhra Pradesh, as a result of upgradation of genetic potential of Nondescript buffaloes with Murrah buffaloes through Artificial Insemination programme, buffaloes are upgraded as Murrah Graded Buffaloes, Guntur, Krishna districts of Andhra Pradesh occupy first and third in buffalo population with 10.07 lakhs and 6.96 lakhs respectively. In these districts, most of the buffalo farms are with 10-30 animals. Keeping in view the role of Body Condition Score in expression of milk production potential of buffaloes, a study was taken up in both the districts i.e Guntur and Krishna with the following objective. To study the relationship between Body Condition Score and milk yield, fat and Solids-not-fat percent in Murrah Graded Buffaloes under field conditions.

\section{MATERIALS AND METHODS:}

A total of one hundred and fifty lactating Murrah graded buffaloes with different parities of various buffalo farms located at various villages like Balusulapalem, Bhattiprolu, Nagaram, Borravaripalem, Dosapalem, Pudivada and Uppuluru were utilized for this study and presented in the Table 1.

To study the relationship between Body Condition Score(BCS) with milk yield, fat and solids-not-fat(SNF) per cent in Murrah graded buffaloes, the animals were visually assessed according to Body Condition Score. The buffaloes of various Body Condition Scores of each animal and the values were used to study the correlation between them to know the effect of parity on the milk yield, fat and SNF per cent. Test day milk yield was recorded, fat percentage and solids-not-fat percentage were tested and other observations were also recorded on the same day.

\section{Body Condition Score (BCS):}

For studying the relationship of Body Condition Score with milk yield, fat and SNF, Body Condition Score of each buffalo was visually observed for eight check points in the body and recorded according to the scale 1 to 5 (emaciated to fat) using 0.5 increments (Anitha et al., 2011). The eight skeletal check points were 1. Tail head to pin bones. 2. Spinous processes of Spinous and Transverse processes.3. Depression between Spinous and 


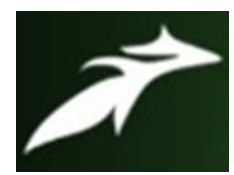

Ranjitha. B et al, International Journal of Advances in Agricultural Science and Technology, Vol.8 Issue.8, August-2021, pg. 33-41

ISSN: 2348-1358

Impact Factor: 6.057

NAAS Rating: 3.77

Transverse processes. 4. Transverse processes of Lumbar vertebrae. 5. Point between 12th and 13th ribs. 6. Sacral crest. 7. Depression between sacral crest and hooks. 8. Depression between hooks and pins. Test day milk yield was taken and the fat percentage and solids-notfat percentage were tested and recorded.

\section{Test Day Milk Yield, Fat and SNF Percent:}

The test day milk yield of the particular buffalo was measured and recorded on the same day. The milk samples were collected for estimation of fat per cent and this was done by using the automatic milk fat analyzer on the same day at the local collection centres. The SNF content of the milk was estimated by using the following Richmond's formula.

$\mathrm{SNF} \%=\frac{\mathrm{CLR}}{4}+0.21 \mathrm{~F}+0.14$

CLR: Corrected Lactometer Reading

F: Fat percent

\section{STATISTICAL ANALYSIS:}

Statistical analysis of the data was carried out according to the procedures suggested by Snedecor and Cochran (1989) and the data obtained on various Body Condition Score were analyzed using an SPSS statistical package (version 17.0) to obtain the mean and standard error (S.E) values in different lactations. The Pearson's correlation coefficient was estimated to study the relationship of BCS with milk yield, fat and SNF percent to find any relationship of these parameters and also to study the overall relationship of BCS with milk yield, fat and SNF percent.

\section{RESULTS:}

\section{Relationship between postpartum BCS and milk yield in Murrah Graded Buffaloes:}

The Mean BCS of the Buffaloes according to the month of lactation were presented in the Table2.The overall Mean $( \pm$ S.E) of BCS and milk yield was $3.51 \pm 0.04$ and $8.62 \pm 0.13 \mathrm{~kg}$ per day respectively. Higher BCS was observed in second month of lactation while the lower was in first month of lactation with a mean value of $3.67 \pm 0.06$ and $3.09 \pm 0.13$ respectively. Maximum and minimum milk yield was observed in second month and first month of lactation with $9.445 \pm 0.15 \mathrm{~kg}$ and $6.18 \pm 0.08 \mathrm{~kg}$ per day respectively.

\section{Correlation of Mean BCS and milk yield in the test herd:}

The relationship between BCS and milk yield was presented in the Table 3. The correlation coefficient between BCS and Milk yield was 0.41. The BCS and milk yield was significantly $(\mathrm{P}<0.01)$ correlated with milk yield.

\section{Average milk yield according to BCS in Murrah Graded Buffaloes:}

The Mean $( \pm$ S.E) value of average milk yield per day according to different BCS were presented in Table 4.The Mean $( \pm$ S.E) milk yield for the BCS groups 2.5-2.99, 3.0-3.49, 3.5-3.99 and 4.0- 4.49 was $7.56 \pm 0.28,8.34 \pm 0.24,8.74 \pm 0.22$ and $9.40 \pm 0.24$ kgs respectively. Highest milk yield was recorded in animals having BCS of 4.0-4.49. 


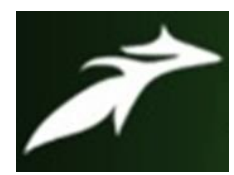

Ranjitha. B et al, International Journal of Advances in Agricultural Science and Technology, Vol.8 Issue.8, August-2021, pg. 33-41

ISSN: 2348-1358

Impact Factor: 6.057

NAAS Rating: 3.77

\section{Milk fat percent according to BCS in Murrah Graded Buffaloes:}

The Mean $( \pm$ S.E) of milk fat per cent according to different BCS has been presented in the Table 5.The fat percent for BCS groups 2.5-2.99, 3.0-3.49, 3.5-3.99 and 4.0-4.49 was7.35 $\pm 0.08,7.36 \pm 0.06,7.49 \pm 0.08$ and $7.60 \pm 0.06$ per cent respectively. BCS group of 4.04.49had the highest milk fat per cent followed those by BCS groups 3.5-3.99, 3.0-3.49 and 2.5-2.99 respectively in that order.

\section{SNF per cent according to different BCS in Murrah Graded Buffaloes:}

The Mean $( \pm$ S.E) of SNF per cent of different BCS groups were presented in the Table 6.The SNF per cent for the BCS groups 2.5-2.99, 3.0-3.49, 3.5-3.99 and 4.0-4.49 were 9.28 \pm 0.03 , $9.41 \pm 0.02,9.44 \pm 0.03$ and $9.50 \pm 0.01$ respectively. BCS group 4.0-4.49 had higher SNF per cent followed by 3.5-3.99, 3.0-3.49 and 2.5-2.99.

Relationship of BCS with milk yield, fat and SNF per cent in Murrah Graded Buffaloes: The relationship of BCS with milk yield, fat per cent and SNF per cent in Murrah Graded Buffaloes had presented in the Table 7.BCS showed positive correlation with milk yield, fat and SNF per cent. BCS had showed high positive correlation with SNF (0.44) and milk yield $(0.41)$.

\section{DISCUSSION:}

\section{Relationship of Body Condition Score with daily milk yield, Fat and SNF percent in} Murrah Graded Buffaloes:

It was observed that the overall mean $( \pm$ S.E) of BCS and milk yield was $3.51 \pm 0.04$ and $8.62 \pm 0.13 \mathrm{~kg}$ per day respectively. It was also revealed that the average milk yield for the BCS groups 2.5-2.99, 3.0-3.49, 3.5-3.99 and 4.0-4.49 was7.56 $\pm 0.28,8.34 \pm 0.24,8.74 \pm 0.22$ and 9.4 \pm 0.24 , respectively. Buffaloes of BCS group 4.0-4.49 had higher milk yield than others which was presented in Figure 1. It was concluded that BCS significantly correlated with SNF (0.44) and milk yield (0.41).

The results revealed that the fat per cent of milk for BCS groups 2.5- 2.99, 3.0-3.49, 3.5-3.99 and 4.0-4.49 was 7.35 $\pm 0.08,7.36 \pm 0.06,7.49 \pm 0.08$ and 7.60 \pm 0.06 ,respectively. Buffaloes of BCS group 4.0-4.49 had higher Fat per cent. There was difference in the fat per cent among all the groups depicted in Figure 2. It was observed that the SNF per cent for the BCS groups 2.5-2.99, 3.0-3.49, 3.5-3.99 and 4.0-4.49 were 9.28 $\pm 0.03,9.41 \pm 0.02,9.44 \pm 0.03$ and $9.50 \pm 0.01$, respectively. Buffaloes of BCS group 4.0-4.49 had higher SNF per cent presented in Figure 3.

These results were in agreement with the results of Ishaq et al., (2011) reported that BCS has direct effect on the milk production in buffaloes and showed that buffaloes having high BCS have higher milk production as compared to buffaloes with low BCS. In contrast to the present study Mushtaq et al., (2012) found that highest milk yield was recorded in buffaloes with moderate BCS. Milk yield decreased and negatively correlated with BCS 


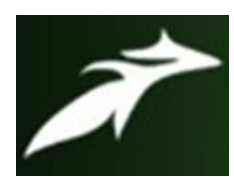

Ranjitha. B et al, International Journal of Advances in Agricultural Science and Technology,

which was contradictory with the present results. Hossain et al., (2013) reported that BCS significantly affected milk yield and fat. Highest milk yield was recorded in moderate BCS (3.00). SNF increased non-significantly with increasing BCS upto 4.0. Petrovska and Jonkus (2014) concluded that milk productivity and quality traits were not affected by body condition score. Ashalatha et al., (2015) showed that milk yield was higher in BCSc group of 3.5-3.99 and also revealed that milk production, peak milk yield, persistency, milk protein, Fat and SNF increased upto a score of 3.99 but beyond this there is decline. Singh et al., (2015) observed that daily milk yield was higher in the group having BCSc of $>3.5$ and significantly correlated with BCS.

Battagin et al., (2014) studied the genetic relationship among milk yield, body condition score and pregnancy rate in Italian Holstein cows and confirmed the antagonist effect of milk yield on BCS. Loker et al., (2009) observed test day records for BCS and concluded that cows with a genetically higher BCS tended to produce less milk. No correlation between BCS and Fat per cent genetically. Hossein-Zadeh and Akbarian et al., (2015) found that correlation between BCS and Fat percentage was low and positive. Anitha et al., (2011) revealed that Buffaloes of BCS group 3.5-3.99 showed the best performance in terms of milk production, peak milk yield, milk protein, solids not Fat. The score beyond there was decline in performance. Samarutel et al., (2006) concluded that Fat group cow produced significantly higher Fat corrected milk (FCM) with high milk Fat percentage.

Table 1: Table showing the number of animals assessed in the villages of Guntur and Krishna districts:

\begin{tabular}{|c|l|c|c|}
\hline $\begin{array}{c}\text { S. } \\
\text { NO }\end{array}$ & VILLAGE & $\begin{array}{c}\text { DIST } \\
\text { RICT }\end{array}$ & $\begin{array}{c}\text { Number } \\
\text { of animals } \\
\text { assessed }\end{array}$ \\
\hline 1 & $\begin{array}{l}\text { Balusu } \\
\text { lapalem }\end{array}$ & Guntur & 10 \\
\hline 2 & Bhattiprolu & Guntur & 40 \\
\hline 3 & Nagaram & Guntur & 20 \\
\hline 4 & $\begin{array}{l}\text { Borravari } \\
\text { palem }\end{array}$ & Guntur & 20 \\
\hline 5 & Dosapalem & Guntur & 20 \\
\hline 6 & Pudivada & Guntur & 20 \\
\hline 7 & Uppuluru & Krishna & 20 \\
\hline
\end{tabular}

Table 2: Lactation stage wise BCS and milk yield in the test herd (Mean \pm S.E)

\begin{tabular}{|c|c|c|}
\hline Stage of lactation & BCS $($ Mean \pm S.E) & Daily milk yield (Mean \pm S.E) \\
\hline 1 & $3.09 \pm 0.13$ & $6.18 \pm 0.08$ \\
\hline 2 & $3.33 \pm 0.08$ & $9.44 \pm 0.15$ \\
\hline 3 & $3.60 \pm 0.09$ & $7.75 \pm 0.20$ \\
\hline 4 & $3.60 \pm 0.09$ & $9.16 \pm 0.25$ \\
\hline Overall (Mean \pm S.E) & $3.51 \pm 0.04$ & $8.62 \pm 0.13$ \\
\hline
\end{tabular}




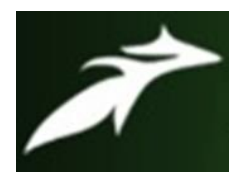

Ranjitha. B et al, International Journal of Advances in Agricultural Science and Technology,

Vol.8 Issue.8, August-2021, pg. 33-41

ISSN: 2348-1358

Impact Factor: 6.057

NAAS Rating: 3.77

Table 3: Correlation of BCS with milk yield in the test herd

*Significant at $(\mathrm{P}<0.01)$.

\begin{tabular}{|l|l|l|}
\hline & Mean BCS & Milk Yield \\
\hline Mean BCS & -- & -- \\
\hline Milk Yield & $0.41^{*}$ & -- \\
\hline
\end{tabular}

Table 4: Daily milk yield according to different BCS in Murrah Graded Buffaloes $($ Mean \pm S.E)

\begin{tabular}{|c|c|}
\hline BCS & $\begin{array}{c}\text { Daily Milk yield } \\
\text { (Mean } \pm \text { S.E) }\end{array}$ \\
\hline $2.5-2.99$ & $7.56 \pm 0.28$ \\
\hline $3.0-3.49$ & $8.34 \pm 0.24$ \\
\hline $3.5-3.99$ & $8.74 \pm 0.22$ \\
\hline $4.0-4.49$ & $9.40 \pm 0.24$ \\
\hline
\end{tabular}

Table 5: Milk fat per cent according to different BCS in Murrah Graded Buffaloes $($ Mean \pm S.E)

\begin{tabular}{|c|c|}
\hline BCS & Fat per cent \\
\hline $2.5-2.99$ & $7.35 \pm 0.08$ \\
\hline $3.0-3.49$ & $7.36 \pm 0.06$ \\
\hline $3.5-3.99$ & $7.49 \pm 0.08$ \\
\hline $4.0-4.49$ & $7.60 \pm 0.06$ \\
\hline
\end{tabular}

Table 6: SNF per cent of different BCS groups in Murrah Graded Buffaloes $($ Mean \pm S.E)

\begin{tabular}{|l|l|}
\hline BCS & SNF Percent \\
\hline $2.5-2.99$ & $9.28 \pm 0.03$ \\
\hline $3.0-3.49$ & $9.41 \pm 0.02$ \\
\hline $3.5-3.99$ & $9.44 \pm 0.03$ \\
\hline $4.0-4.49$ & $9.50 \pm 0.01$ \\
\hline
\end{tabular}

Table 7: Correlation of BCS with milk yield, fat and SNF per cent in Murrah Graded Buffaloes

\begin{tabular}{|c|l|l|l|l|}
\hline & BCS & Milk yield & Fat & SNF \\
\hline BCS & 1 & & & \\
\hline Milk yield & $0.41^{* *}$ & 1 & & \\
\hline Fat & $0.25^{* *}$ & $0.49^{* *}$ & 1 & \\
\hline SNF & $0.44^{* *}$ & $0.45^{* *}$ & $0.78^{* *}$ & 1 \\
\hline
\end{tabular}

** Significant at $(\mathrm{P}<0.01)$. 


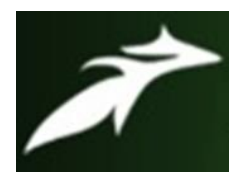

Ranjitha. B et al, International Journal of Advances in Agricultural Science and Technology, Vol.8 Issue.8, August-2021, pg. 33-41

ISSN: 2348-1358

Impact Factor: 6.057

NAAS Rating: $\mathbf{3 . 7 7}$

Figure 1. Average milk yield per day according to different BCS in Murrah Graded Buffaloes

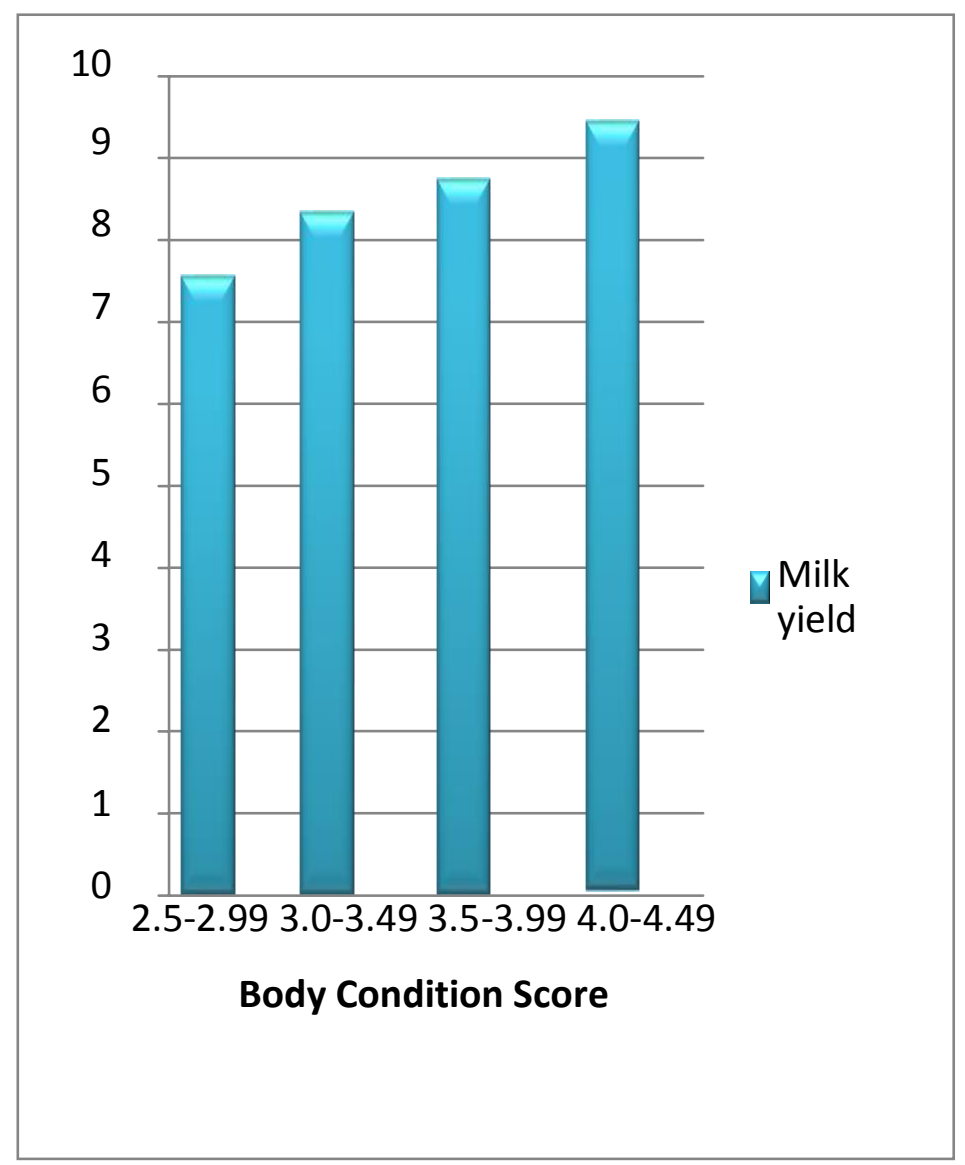

Figure 2. Average Fat per cent according to different BCS in Murrah Graded Buffaloes

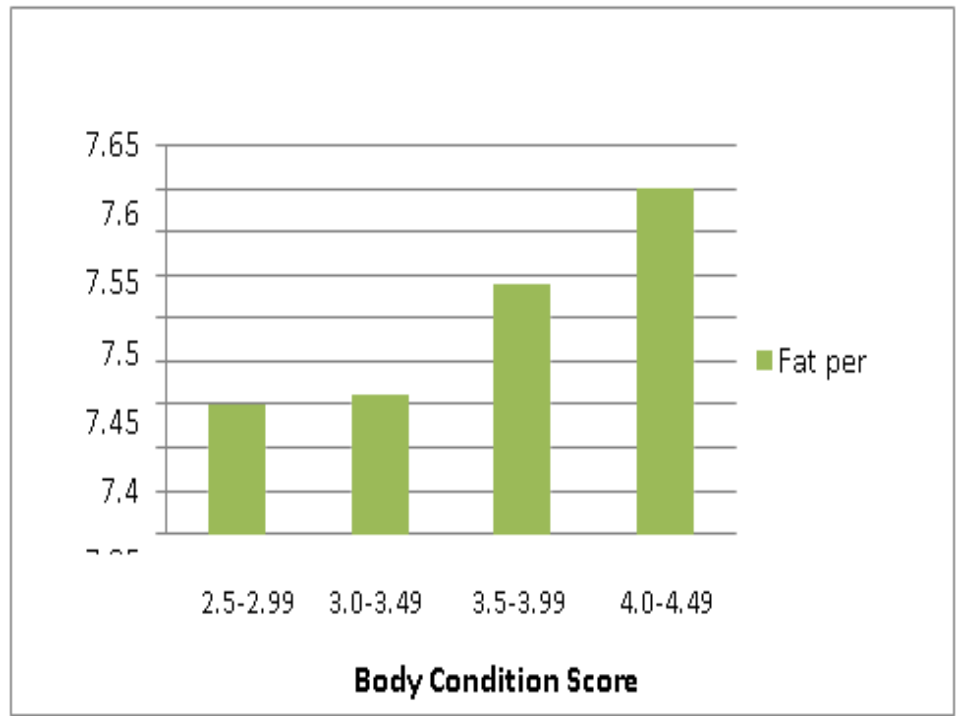




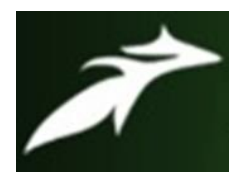

Ranjitha. B et al, International Journal of Advances in Agricultural Science and Technology,

Vol.8 Issue.8, August-2021, pg. 33-41

ISSN: 2348-1358

Impact Factor: 6.057

NAAS Rating: 3.77

Figure 3. Average SNF per cent according to different BCS in Murrah Graded Buffaloes

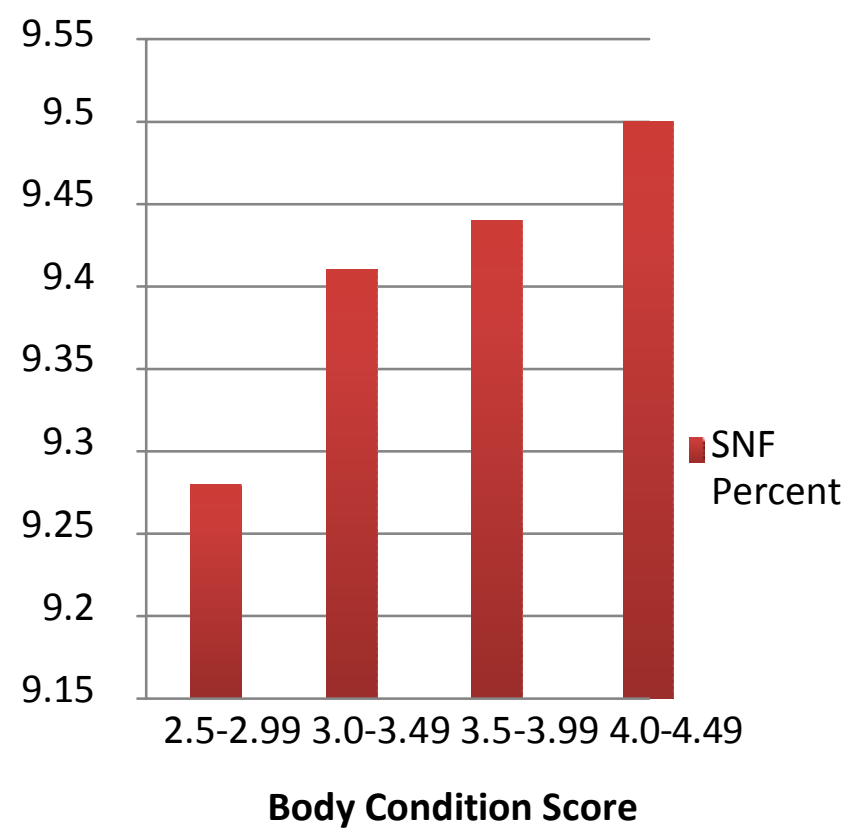

\section{REFERENCES}

[1]. Anitha A, Rao K S, Suresh J, Moorthy P S and Reddy Y K 2011 A body condition score (BCS) system in Murrah buffaloes. Buffalo Bulletin 30(1):79-99.

[2]. Ashalatha P, Sarjan Rao K, Jagadeeswara Rao S, Ravindra Reddy Y., Moorthy P R S and Ramana J V 2015 Study on the relationship of BCSc and lactation curve characteristics in Murrah and graded Murrah buffaloes under field conditions. International Journal of Food, Agriculture and Veterinary Sciences ISSN:2277- 209X.

[3]. Battagin M, Tiezzi F, Cassandro M and Maltecca C 2014 Causal Relationships Between Milk Yield, Body Condition Score and Fertility in Italian Holstein Friesian Dairy Cattle. Proceedings, 10th World Congress of Genetics Applied to Livestock Production.

[4]. GOI. 2018. State/UT wise Buffalo Milk Production in India from 2013-14 to 2015-16, Community.org.in. Open Government Data (ODG) Platform India, as accessed on 10/10/2018.

[5]. Hossain M E, Chanda T, Debnath G K, Hasan M M, Shaikat A H and Hoque M A 2015 Influence of Body Condition Score on Yield and Composition of Milk in Crossbred Dairy Cows. Iranian Journal of Applied Animal Science 5(2):309-315.

[6]. Hossein-Zadeh N G and Akbarian M 2015 Factors Affecting Body Condition Score and Its Relationship with Productive and Reproductive Performances of Holstein Cows. Iranian Journal of Applied Animal Science 5(1) 73-79. 


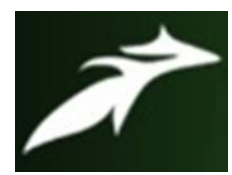

Ranjitha. B et al, International Journal of Advances in Agricultural Science and Technology, Vol.8 Issue.8, August-2021, pg. 33-41

ISSN: 2348-1358

Impact Factor: 6.057

NAAS Rating: 3.77

[7]. Ishaq M, Warriach H M, McGill D, Bush R D, Arif S, Murtaza N and Wynn P C 2011 Effect of body condition score on milk production and reproductive disorders in buffalo. In SAADC 2011 strategies and challenges for sustainable animal agriculturecrop systems, Volume III: full papers. Proceedings of the 3rd International Conference on sustainable animal agriculture for developing countries, Nakhon Ratchasima, Thailand, 26-29 July, 2011(pp. 659-661). Suranaree University of Technology.

[8]. Loker S, Bastin C, Miglior F, Sewalem A, Fatehi J, Schaeffer L R and Jamrozik J 2009 Genetic parameters of body condition score and milk production traits in Canadian Holsteins. In Dairy Cattle Breeding and Genetics Committee Meeting, Centre for Genetic Improvement of Livestock, University of Guelph (Canada) (p. 11).

[9]. Mushtaq A, Qureshi M S, Khan S, Habib G, Swati Z A and Rahman S U 2012 Body condition score as a marker of milk yield and composition in dairy animals. The Journal of Animal and Plant Sciences 22(Suppl 3):169-173.

[10].Petrovska S and Jonkus D 2014 Relationship between body condition score, milk productivity and live weight of dairy cows. In Research for Rural Development. International Scientific Conference Proceedings (Latvia) Latvia University of Agriculture.

[11].Samarutel J, Ling K, Jaakson H, Kaart T and Kart O 2006 Effect of body condition score at parturition on the production performance, fertility and culling in primiparous Estonian Holstein cows Vet Zootech 36(58):69-74.

[12].Singh V, Singh VK, Singh SP, Sahoo B 2015 The Effect of Body Condition Score at Calving on Milk Yield, Milk Composition and Udder Health Status of Dairy Animals. Journal of Dairy Veterinaryand Animal Research 2:00029. 